\title{
EKSPERIMENTASI STRATEGI PEMBELAJARAN MATEMATIKA BERBASIS MASALAH (PROBLEM SOLVING) DAN KONTEKSTUAL (CONTEXTUAL TEACHING AND LEARNING) DITINJAU DARI GAYA BELAJAR SISWA DI SMPN 1 MARTAPURA
}

\author{
Arif Ganda Nugroho
}

\begin{abstract}
Abstrak
Penelitian ini bertujuan (1) Untuk mengetahui keefektifan strategi pembelajaran Problem Solving dan strategi pembelajaran CTL terhadap prestasi belajar matematika siswa, (2) Untuk mengetahui prestasi belajar matematika mana yang lebih baik siswa dengan gaya belajar siswa auditorial, kinestetik, atau visual, (3) Untuk mengetahui pada strategi pembelajaran Problem Solving, mana yang lebih baik prestasi belajar matematika siswa dengan gaya belajar auditorial, kinestetik, atau visual, (4) Untuk mengetahui pada strategi pembelajaran CTL, mana yang lebih baik prestasi belajar matematika siswa dengan gaya belajar auditorial, kinestetik, atau visual.

Jenis penelitian ini adalah penelitian eksperimental semu. Populasi penelitian adalah seluruh siswa kelas VII SMPN 1 Martapura Tahun Pelajaran 2014/2015. Pengambilan sampel menggunakan Stratified Cluster Random Sampling. Ukuran sampel pada penelitian ini adalah 191 siswa. Metode pengumpulan data yang digunakan dalam penelitian ini adalah metode dokumentasi, metode angket, dan metode tes. Instrumen yang digunakan untuk mengetahui prestasi belajar matematika adalah tes pilihan ganda. Adapun instrumen yang digunakan untuk mengetahui gaya belajar siswa adalah berupa angket.

Kesimpulan dari penelitian ini adalah: (1) Prestasi belajar matematika siswa dengan strategi pembelajaran problem solving lebih baik dibandingkan dengan prestasi belajar matematika siswa dengan strategi pembelajaran CTL, (2) Prestasi belajar matematika siswa dengan gaya belajar auditorial sama dengan prestasi belajar matematika siswa dengan gaya belajar kinestetik, prestasi belajar matematika siswa dengan gaya belajar kinestetik sama dengan prestasi belajar matematika siswa dengan gaya belajar visual, prestasi belajar matematika siswa dengan gaya belajar auditorial sama dengan prestasi belajar matematika siswa dengan gaya belajar visual, (3) Pada kelompok siswa dengan strategi pembelajaran problem solving, prestasi belajar matematika
\end{abstract}


siswa dengan gaya belajar auditorial sama dengan prestasi belajar matematika siswa dengan gaya belajar kinestetik, prestasi belajar matematika siswa dengan gaya belajar kinestetik sama dengan prestasi belajar matematika siswa dengan gaya belajar visual, prestasi belajar matematika siswa dengan gaya belajar auditorial sama dengan prestasi belajar matematika siswa dengan gaya belajar visual, (4) Pada kelompok siswa dengan strategi pembelajaran CTL, prestasi belajar matematika siswa dengan gaya belajar auditorial sama dengan prestasi belajar matematika siswa dengan gaya belajar kinestetik, prestasi belajar matematika siswa dengan gaya belajar kinestetik sama dengan prestasi belajar matematika siswa dengan gaya belajar visual, siswa dengan gaya belajar auditorial sama dengan prestasi belajar matematika siswa dengan gaya belajar visual.

Kata Kunci: strategi pembelajaran, problem solving, CTL, Prestasi belajar dan gaya belajar

\section{Pendahuluan}

Berdasarkan penelitian yang dilakukan oleh TIMMS yang dipublikasikan 26 Desember 2006, jumlah jam pengajaran matematika di Indonesia jauh lebih banyak dibandingkan Malaysia dan Singapura. Dalam satu tahun, siswa kelas 7 di Indonesia rata-rata mendapat 169 jam pelajaran matematika. Sementara di Malaysia hanya mendapat 120 jam dan Singapura 112 jam. Tapi kenyataannya, prestasi Indonesia berada jauh di bawah kedua negara tersebut. Prestasi matematika siswa Indonesia hanya menembus skor rata-rata 411. Sementara itu, Malaysia mencapai 508 dan Singapura 605 (400 = rendah, $475=$ menengah, $550=$ tinggi, dan $625=$ tingkat lanjut). Artinya "Waktu yang dihabiskan siswa Indonesia di sekolah tidak sebanding dengan prestasi yang diraih”. (zainurie.wordpress.com).

Berdasarkan Laporan Hasil dan Statistika Nilai Ujian Nasional (UN) SMP Tahun Pelajaran 2013/2014 diperoleh rerata nilai matematika siswa SMP Kabupaten Banjar adalah 6,94 dengan nilai tertinggi 10,00, terendah 1,00 dan standar deviasi 2,01. Sedangkan rerata nilai matematika siswa SMP Provinsi Kalimantan Selatan adalah 7,30 dengan nilai tertinggi 10,00, terendah 0,25 dan standar deviasi 1,74. Jika dibandingkan dengan rerata 
Eksperimentasi Strategi Pembelajaran Matematika Berbasis Masalah (Problem Solving) dan Kontekstual (Contextual Teaching and Learning) Ditinjau Dari Gaya Belajar Siswa di SMPN 1 Martapura

provinsi, rerata nilai matematika siswa SMP Kabupaten Banjar lebih rendah dari rerata provinsi. Data tersebut membuktikan bahwa penguasaan materi pelajaran matematika siswa yang masih kurang.

Menurut data dan kenyataan di atas, dapat disimpulkan bahwa belum maksimalnya pendidikan matematika di Indonesia, Sehingga belum dapat meningkatkan kualitas kemampuan matematika siswa Indonesia. Dalam meningkatkan kualitas pendidikan matematika, selain jam pelajaran, perlu diketahui faktor-faktor yang mempengaruhi pendidikan matematika. Terdapat beberapa faktor yang mempengaruhi proses belajar mengajar matematika antara lain: strategi pembelajaran yang dipilih oleh guru, gaya belajar siswa, motivasi belajar siswa, minat belajar siswa, lingkungan belajar siswa dan tingkat kecerdasan siswa.

Ada kemungkinan penyebab rendahnya prestasi belajar matematika siswa pada saat ini adalah karena pelaksanaan pembelajaran matematika di sekolah itu masih bersifat konvensional (siswa pasif dan guru mendominasi proses pembelajaran). Dalam hal ini guru berusaha menyelesaikan bahan ajar dengan cara menyampaikan materi secara langsung kepada siswa. Cara seperti ini sangatlah bertentangan dengan teori konstruktivisme yang lebih menekankan kepada keaktifan siswa dalam membangun pengetahuan mereka sendiri. Tentunya pembelajaran yang seperti disebutkan di atas (guru sangat dominan), hendaknya ditinggalkan atau setidak tidaknya dikurangi.

Salah satu strategi pembelajaran yang dapat digunakan guru adalah strategi pembelajaran berbasis masalah (Problem Solving) merupakan konsep belajar yang mengaitkan materi yang diajarkan dengan masalah yang dihadapi sehari-hari. Dalam strategi pembelajaran ini, siswa diharapkan dapat menyelesaikan masalah matematika sesuai dengan pemahaman masing-masing siswa berlandaskan pada pengetahuan yang telah dimiliki. Dengan strategi ini diharapkan pembelajaran semakin bermakna bagi siswa, sehingga apa yang sudah didapatkan tidak mudah lupa. Proses pembelajaran dengan Problem Solving berlangsung alamiah 
dalam bentuk kegiatan siswa bekerja dan mengalami, bukan hanya mentransfer pengetahuan dari guru ke siswa.

Selain strategi pembelajaran berbasis masalah (Problem Solving), guru juga dapat menggunakan strategi pembelajaran kontekstual (Contextual Teaching and Learning/CTL). CTL merupakan strategi pembelajaran yang membantu guru mengaitkan antara materi yang diajarkan dengan situasi dunia nyata siswa dan mendorong siswa membuat hubungan antara pengetahuan yang dimilikinya dengan penerapannya dalam kehidupan mereka sebagai angota keluarga dan masyarakat. Dalam strategi pembelajaran ini, tugas guru membantu siswa mencapai tujuannya. Tugas guru mengelola kelas sebagai sebuah tim yang bekerjasama untuk menemukan sesuatu yang baru bagi siswa. Sesuatu yang baru itu berupa pengetahuan dan keterampilan yang merupakan hasil dari penemuan siswa itu sendiri, bukan dari "apa kata guru”. Pembelajaran kontekstual ini dikembangkan dengan tujuan agar pembelajaran berjalan lebih bermakna dan lebih produktif. Dengan strategi ini diharapkan pembelajaran matematika akan semakin bermakna bagi siswa, sehingga pelajaran yang sudah didapatkan tidak mudah lupa.

Selain motivasi belajar yang kurang, ada kemungkinan dalam proses pembelajarannya di dalam kelas sebagian besar guru juga kurang atau tidak memperhatikan gaya belajar siswa. Tidak semua siswa yang ada di dalam kelas mempunyai gaya belajar yang sama. Kemungkinan antara siswa yang satu dengan yang lain berbeda cara dalam mempelajari suatu materi pelajaran. Berkaitan dengan gaya belajar tersebut, kemungkinan siswa memiliki salah satu gaya belajar yang lebih dominan dalam dirinya, meski kemungkinan gaya belajar lainnya juga dapat mereka miliki. Kemungkinan seorang siswa dapat memiliki gaya belajar dengan cara melihat (visual). Kemungkinan pula seorang siswa mempunyai gaya belajar dengan cara mendengar (auditorial). Di samping itu, seorang siswa juga dapat memiliki gaya belajar dengan cara bergerak, bekerja, dan menyentuh (kinestetik). Jika guru mampu memperhatikan dan mengoptimalkan gaya belajar setiap 
Eksperimentasi Strategi Pembelajaran Matematika Berbasis Masalah (Problem Solving) dan Kontekstual (Contextual Teaching and Learning) Ditinjau Dari Gaya Belajar Siswa di SMPN 1 Martapura

siswa tersebut, kemungkinan hasil belajar siswa dapat tercapai dengan optimal.

Dalam belajar matematika, untuk dapat memahami konsep-konsep matematika, menganalisis, dan menarik kesimpulan, siswa dituntut untuk dapat memahami dua hal pokok tentang matematika. Pertama, siswa harus mampu memahami teori, hukum, dan aturan yang diperoleh. Kedua, siswa harus memahami cara mendapatkan dari yang disebutkan sebelumnya. Dari dua hal pokok tentang belajar matematika tersebut dapat diartikan bahwa pembelajaran matematika tidak hanya cukup menghafal konsep-konsep matematika saja. Akan tetapi bagaimana konsep, anturan, dan hukum itu dipahami dan bagaimana pula memahami cara-cara memperolehnya.

Jika diteliti lebih mendalam, berdasarkan Laporan Hasil dan Statistika Nilai Ujian Nasional (UN) SMP Tahun Pelajaran 2013/2014. Persentase penguasaan materi soal matematika dibagi menjadi beberapa aspek diantaranya adalah kemampuan untuk menyelesaikan soal cerita yang berkaitan dengan perbankan dan koperasi. Hasil persentase untuk aspek ini sebagai berikut: untuk tingkat Provinsi Kalimantan Selatan 66,27 dan untuk tingkat rayon Kabupaten Banjar 60,06. Dari data tersebut nampak bahwa nilai untuk rayon Kabupaten Banjar jauh lebih rendah dari presentasi Provinsi Kalimantan Selatan.

Dalam hal ini, aspek tersebut terdapat pada pokok bahasan Aritmetika Sosial pada pelajaran matematika kelas VII semester 1 . Berdasarkan observasi yang dilakukan di beberapa Sekolah Menengah Pertama (SMP) di Kabupaten Banjar, kebanyakan dari guru mengajarkan pelajaran matematika khususnya pokok bahasan Aritmetika Sosial dengan menggunakan pembelajaran konvensional.

\section{Metode Penelitian}

Penelitian ini merupakan penelitian eksperimental semu (Quasi experimental research) karena dalam penelitian ini tidak memungkinkan mengontrol semua variabel yang relevan kecuali beberapa variabel yang 
diteliti. Dalam penelitian ini terdapat dua variabel bebas yaitu strategi pembelajaran dan gaya belajar, satu variable terikat yaitu prestasi belajar matematika.

Dalam penelitian ini, menggunakan dua kelas eksperimen yaitu kelas eksperimental I dengan menggunakan strategi pembelajaran problem solving dan kelas eksperimental II dengan menggunakan strategi pembelajaran CTL. Sebelum diberi perlakuan, terlebih dahulu dilakukan uji keseimbangan. Hal ini bertujuan untuk mengetahui apakah kelas eksperimen I dan kelas eksperimen II dalam keadaan seimbang atau tidak. Data yang digunakan untuk menguji keseimbangan adalah nilai Ujian Tengah Semester (UTS) matematika siswa. Pada akhir eksperimen, kedua kelas tersebut diukur dengan menggunakan alat ukur yang sama yaitu soalsoal tes prestasi belajar matematika. Hasil pengukuran tersebut dianalisis dan dibandingkan dengan uji statistik yang digunakan.

Dalam penelitian ini populasinya adalah seluruh siswa kelas VII SMPN 1 Martapura yang terdiri dari 9 kelas. Sampel dalam penelitian ini menggunakan enam kelas yaitu tiga kelas eksperimental I yang dikenai perlakuan berupa strategi pembelajaran Problem Solving dan tiga kelas eksperimental II yang dikenai perlakuan berupa strategi pembelajaran CTL. Hasil dari penelitian ini akan digunakan untuk melakukan generalisasi terhadap seluruh populasi yang ada. Dalam penelitian ini, sampel diambil dengan sampling random kluster. Sampling random kluster adalah sampling random yang dikenakan berturut-turut terhadap unit-unit atau sub-sub populasi. Unit-unit atau sub-sub populasi disebut kluster. Dalam pengambilan dengan cara ini, kluster-kluster yang ada dianggap homogen (sama antara satu dengan yang lainnya) (Budiyono, 2003: 37).

Terdapat dua macam variabel dalam penelitian ini, yaitu variabel independen (variabel bebas) dan varibel dependen (variabel terikat). Variabel bebas yaitu Strategi pembelajaran Problem Solving, strategi pembelajaran CTL, gaya belajar. Sementara itu, yang menjadi variabel terikat yaitu prestasi belajar matematika. 
Eksperimentasi Strategi Pembelajaran Matematika Berbasis Masalah (Problem Solving) dan Kontekstual (Contextual Teaching and Learning) Ditinjau Dari Gaya Belajar Siswa di SMPN 1 Martapura

Teknik Pengumpulan data dalam penelitian ini adalah tes tertulis, angket, dan dokumentasi. Metode tes dalam penelitian ini digunakan untuk mengumpulkan data mengenai prestasi belajar matematika siswa. Data tentang prestasi belajar matematika siswa diperoleh dari instrumen tes yang dibuat oleh peneliti. Instrumen yang digunakan untuk mengumpulkan data tentang prestasi belajar matematika siswa diujicobakan terlebih dahulu untuk mengetahui daya beda, tingkat kesukaran dan reliabilitas.. Sedangkan instrumen penelitian yang digunakan dalam penelitian ini adalah instrumen tes bentuk pilihan ganda. Pemberian skor item tes adalah skor 1 untuk jawaban benar dan skor 0 untuk jawaban salah. Untuk menguji butir instrumen digunakan uji daya beda dan tingkat kesukaran.

Menurut Budiyono (2003:47), metode angket adalah “cara pengumpuulan data melalui pengajuan pertanyaan-pertanyaan tertulis kepada subjek penelitian, responden, atau sumber data dan jawaban diberikan pula secara tertulis". Adapun prosedur pemberian skor dengan metode angket ini yaitu:

1. Item positif

Tabel 1. Skor Butir Angket Positif

\begin{tabular}{|l|c|c|c|c|}
\hline Pernyataan & Selalu & Sering & Kadang-kadang & Tidak pernah \\
\hline Skor & 4 & 3 & 2 & 1 \\
\hline
\end{tabular}

2. Item negatif

Tabel 2. Skor Butir Angket Negatif

\begin{tabular}{|l|c|c|c|c|}
\hline Pernyataan & Selalu & Sering & Kadang-kadang & Tidak pernah \\
\hline Skor & 1 & 2 & 3 & 4 \\
\hline
\end{tabular}

Angket dalam penelitian ini bertujuan untuk mengetahui gaya belajar matematika siswa. Langkah-langkah dalam penyusunan angket gaya belajar matematika adalah:

a. Menentukan batasan instrumen angket untuk masing-masing gaya belajar 
b. Menyusun kisi-kisi angket yang didalamnya memuat indikator mengenai masing-masing gaya belajar matematika siswa.

c. Menyusun instrumen angket berdasarkan kisi-kisi.

d. Menentukan cara pemberian skor pada setiap butir angket.

e. Menelaah butir angket. Penelaahan ini dilakukan oleh validator untuk mengetahui kevalidan dari butir angket menurut isinya. Sesuatu instrumen valid menurut validitas isi apabila isi instrumen tersebut telah merupakan sampel yang representatif dari keseluruhan isi hal yang akan diukur.

f. Melakukan uji coba dan kemudian menganalisis butir angket.

g. Untuk mentukan siswa masuk dalam gaya belajar visual, kinestetik atau auditorial, dilihat pada jumlah skor pada tes angket pada masing-masing gaya belajar.

h. Setelah diujicobakan, butir yang tidak baik tidak digunakan dalam penelitian ini.

Untuk mengetahui baik atau tidaknya angket tersebut dilakukan validitas isi, uji kosistensi internal dan uji reliabilitas pada masing-masing gaya belajar. Dalam penelitian ini, metode dokumentasi digunakan untuk memperoleh data awal yaitu nama dan nilai ulangan tengah semester (UTS) semester I kelas VII pada pelajaran matematika. Pengumpulan data ini dimaksudkan untuk mengetahui keadaan awal tentang prestasi belajar matematika dari sampel yang dipilih, sebelum dikenahi perlakuan. Data yang diperoleh akan digunakan untuk uji keseimbangan rata-rata.

Teknis analisis data yang digunakan dalam penelitian ini adalah :

\section{Uji Prasyarat}

\section{a. Uji Normalitas}

Uji normalitas nilai awal digunakan untuk mengetahui apakah sampel yang akan digunakan dalam penelitian ini berasal dari populasi yang berdistribusi normal atau tidak. Oleh karena data tidak dalam distribusi 
Eksperimentasi Strategi Pembelajaran Matematika Berbasis Masalah (Problem Solving) dan Kontekstual (Contextual Teaching and Learning) Ditinjau Dari Gaya Belajar Siswa di SMPN 1 Martapura

frekuensi data bergolong, maka akan digunakan metode Lilliefors dengan prosedur uji sebagai berikut (Budiyono, 2009: 170-171).

1. Hipotesis

$\mathrm{H}_{0}$ : sampel berasal dari populasi yang berdistribusi normal

$\mathrm{H}_{1}$ : sampel tidak berasal dari populasi yang berdistribusi normal

2. Taraf signifikansi: $\alpha=0,05$

3. Statistik uji

$$
\mathrm{L}=\text { Maks }\left|F\left(z_{i}\right)-S\left(z_{i}\right)\right|
$$

Keterangan:

$\mathrm{F}\left(\mathrm{z}_{\mathrm{i}}\right)=\mathrm{P}\left(\mathrm{Z}<\mathrm{z}_{\mathrm{i}}\right) ; \mathrm{Z} \sim \mathrm{N}(0,1)$

$\mathrm{S}\left(\mathrm{z}_{\mathrm{i}}\right)=$ proporsi cacah $\mathrm{Z}_{\leq} \mathrm{Z}_{\mathrm{i}}$ terhadap seluruh $\mathrm{z}$

4. Daerah kritik (DK)

$\mathrm{DK}=\left\{\mathrm{L} \mid \mathrm{L}>\mathrm{L}_{\alpha ; \mathrm{n}}\right\}$ dengan $\mathrm{n}$ ukuran sampel

5. Keputusan uji

$\mathrm{H}_{0}$ ditolak jika $\mathrm{L} \in \mathrm{DK}$

\section{b. Uji Homogenitas}

Uji homogenitas nilai awal digunakan untuk mengetahui apakah sampel-sampel yang akan digunakan dalam penelitian ini berasal dari populasi yang bervariansi sama. Untuk melakukannya, digunakan uji Bartlett dengan prosedur uji sebagai berikut (Budiyono, 2009: 176-177).

1) Hipotesis

$\mathrm{H}_{0}: \sigma_{1}^{2}=\sigma_{2}^{2}=\sigma_{3}^{2}=\ldots=\sigma_{k}^{2}$ (populasi-populasi homogen)

$\mathrm{H}_{1}$ : paling sedikit ada dua variansi yang tidak sama (tidak berasal dari populasi yang homogen)

2) Taraf signifikansi: $\alpha=0,05$

3) Statistik uji

$$
\chi^{2}=\frac{2.303}{c}\left(f \log R K G-\Sigma f_{j} \log s_{j}^{2}\right)
$$


Arif Ganda Nugroho

Keterangan:

$$
\begin{aligned}
& \chi^{2} \sim \chi_{(\mathrm{k}-1)}^{2} \\
& \mathrm{k}=\text { banyak sampel } \\
& \mathrm{N} \quad=\text { banyak seluruh nilai (ukuran) } \\
& \mathrm{n}_{\mathrm{j}} \quad=\text { ukuran sampel ke-j } \\
& \mathrm{f}_{\mathrm{j}}=\mathrm{n}_{\mathrm{j}}-1=\text { derajat kebebasan untuk } \mathrm{s}_{\mathrm{j}}{ }^{2} ; \mathrm{j}=1,2, \ldots, \mathrm{k} \\
& \mathrm{f}=\mathrm{N}-\mathrm{k} \sum_{j=1}^{k} \mathrm{f}_{\mathrm{j}}=\text { derajat kebebasan untuk RKG } \\
& c=1+\frac{1}{3(k-1)}\left(\sum \frac{1}{f_{j}}-\frac{1}{f}\right) \\
& \text { RKG }=\text { rerata kuadrat galat }=\frac{\sum S S_{j}}{\sum f_{j}} \\
& S S_{j}=\sum X_{j}^{2}-\frac{\left(\sum X_{j}\right)^{2}}{n_{j}}=\left(n_{j}-1\right) s_{j}^{2}
\end{aligned}
$$

4) Daerah kritik (DK)

$$
\mathrm{DK}=\left\{\chi^{2} \mid \chi^{2}>\chi^{2}(\alpha ; k-1)\right\}
$$

5) Keputusan uji

$\mathrm{H}_{0}$ ditolak jika $\chi^{2} \in \mathrm{DK}$

\section{Uji Keseimbangan}

Uji keseimbangan digunakan untuk mengetahui apakah kelompok eksperimen I dan kelompok eksperimen II dalam keadaan seimbang atau tidak sebelum perlakuan dikenakan kepada masing-masing kelompok eksperimen. Oleh karena itu, dilakukan uji sebagai berikut.

1) Hipotesis

$\mathrm{H}_{0}: \mu_{1}=\mu_{2}$ (kedua kelompok berasal dari populasi yang berkemampuan awal sama)

$\mathrm{H}_{1}: \quad \mu_{1} \neq \mu_{2}$ (kedua kelompok tidak berasal dari populasi yang berkemampuan awal sama)

2) Taraf signifikansi: $\alpha=0,05$ 
Eksperimentasi Strategi Pembelajaran Matematika Berbasis Masalah (Problem Solving) dan Kontekstual (Contextual Teaching and Learning) Ditinjau Dari Gaya Belajar Siswa di SMPN 1 Martapura

3) Statistik uji:

$$
\mathrm{t}=\frac{\left(\bar{X}_{1}-\bar{X}_{2}\right)}{s_{p} \sqrt{\frac{1}{n_{1}}+\frac{1}{n_{2}}}} \sim \mathrm{t}\left(n_{1}+n_{2}-2\right)
$$

dengan:

$$
s_{p}^{2}=\frac{\left(n_{1}-1\right) s_{1}^{2}+\left(n_{2}-1\right) s_{2}^{2}}{n_{1}+n_{2}-2} \quad(\text { Budiyono, 2009: 151) }
$$

Keterangan:

$\mathrm{t} \quad=$ harga statistik yang di uji $\mathrm{t}$

$\overline{X_{1}}=$ rata-rata nilai ulangan harian mata pelajaran matematika pada kelompok eksperimen I

$\overline{X_{2}}=$ rata-rata nilai ulangan harian mata pelajaran matematika pada kelompok eksperimen II

$s_{1}^{2}=$ variansi kelompok eksperimen $\mathrm{I}$

$s_{2}^{2} \quad=$ variansi kelompok eksperimen II

$\mathrm{n}_{1} \quad=$ jumlah siswa kelompok eksperimen I

$\mathrm{n}_{2} \quad$ = jumlah siswa kelompok eksperimen II

4) Daerah kritik (DK)

$\mathrm{H}_{0}$ ditolak jika DK $=\left\{\mathrm{t} \mid \mathrm{t}>t_{\left(\frac{\alpha}{2} ; n_{1}+n_{2}-2\right)}\right.$ atau $\left.\mathrm{t}<-t_{\left(\frac{\alpha}{2} ; n_{1}+n_{2}-2\right)}\right\}$

5) Keputusan uji

$\mathrm{H}_{0}$ ditolak jika $\mathrm{t} \in \mathrm{DK}$

\section{Hasil Penelitian}

\section{Deskripsi Data Skor Prestasi Belajar Matematika Siswa}

Dari data prestasi belajar matematika siswa pada kelompok eksperimen I dan kelompok eksperimen II, kemudian ditentukan ukuran tendensi sentralnya yang meliputi rataan $(\bar{X})$, median $(M e)$, modus (Mo), dan ukuran dispersi meliputi jangkauan (J), dan simpangan baku (s), sebagaimana disajikan dalam tabel berikut ini : 
Tabel 3. Deskripsi Data Prestasi Belajar Matematika

\begin{tabular}{|l|c|c|c|c|c|c|c|}
\hline \multirow{2}{*}{ Kelompok } & \multicolumn{3}{|c|}{$\begin{array}{c}\text { Ukuran } \\
\text { Tendensi Sentral }\end{array}$} & \multicolumn{4}{c|}{ Ukuran Dispersi } \\
\cline { 2 - 8 } & $\overline{\boldsymbol{X}}$ & Mo & Me & $\begin{array}{c}\text { Skor } \\
\text { max }\end{array}$ & $\begin{array}{c}\text { Skor } \\
\text { min }\end{array}$ & J & S \\
\hline Eksperimen I & 7,6354 & 7,83 & 7,83 & 10 & 4,35 & 5,65 & 1,5343 \\
\hline Eksperime II & 7,1433 & 7,39 & 7,39 & 10 & 3,04 & 5,96 & 1,3986 \\
\hline
\end{tabular}

\section{Deskripsi Data Skor Angket Gaya Belajar Siswa}

Data tentang gaya belajar siswa diperoleh dari angket gaya belajar. Selanjutnya data tersebut dikelompokkan dalam tiga tipe gaya belajar yaitu auditorial, kinestetik, visual. Pada masing-masing tipe terdiri atas 11 pernyataan dan pada tiap pernyataan terdapat 4 opsi jawaban yang harus dipilih siswa. Skor maksimal pada tiap opsi jawaban pada tiap pernyataan adalah 4 dan skor minimalnya adalah 1 jadi skor maksimum yang diperoleh pada masing-masing tipe gaya belajar adalah 44 . Untuk menentukan tipe gaya belajar yang dimiliki oleh siswa dilihat dari skor tetinggi yang diperoleh pada masing-masing tipe gaya belajar.

Berdasarkan data yang diperoleh pada kelompok eksperimen I terdapat 23 siswa dengan gaya belajar auditorial, 28 siswa dengan gaya belajar kinestetik dan 44 siswa dengan gaya belajar visual. Sedangkan pada kelompok eksperimen II terdapat 19 siswa dengan gaya belajar auditorial, 37 siswa dengan gaya belajar kinestetik dan 40 siswa dengan gaya belajar visual. Sebagaimana disajikan pada tabel berikut ini :

Tabel 4. Deskripsi Data Gaya Belajar Siswa

\begin{tabular}{|l|c|c|}
\hline \multirow{2}{*}{ Gaya belajar } & \multicolumn{2}{|c|}{ Jumlah siswa } \\
\cline { 2 - 3 } & $\begin{array}{c}\text { Kelompok } \\
\text { Eksperimen I }\end{array}$ & $\begin{array}{c}\text { Kelompok } \\
\text { Eksperimen II }\end{array}$ \\
\hline Auditorial & 23 & 19 \\
\hline Kinestetik & 28 & 37 \\
\hline Visual & 44 & 40 \\
\hline
\end{tabular}


Eksperimentasi Strategi Pembelajaran Matematika Berbasis Masalah (Problem Solving) dan Kontekstual (Contextual Teaching and Learning) Ditinjau Dari Gaya Belajar Siswa di SMPN 1 Martapura

\section{Uji Prasyarat Analisis Variansi}

\section{a. Uji normalitas}

Uji normalitas digunakan untuk mengetahui apakah sampel penelitian berasal dari populasi yang berdistribusi normal atau tidak. Uji normalitas masing-masing sampel dilakukan dengan menggunakan metode Lilliefors. Berdasarkan uji normalitas pada setiap kelompok eksperimen dan gaya belajar yang telah dilakukan diperoleh harga statistik uji untuk taraf signifikansi 0,05 pada masingmasing sampel sebagai berikut:

Tabel 5. Hasil Uji Normalitas

\begin{tabular}{|l|l|l|l|c|}
\hline Uji Normalitas & $\mathrm{L}_{\text {maks }}$ & $\mathrm{L}_{0,05 ; \mathrm{n}}$ & Keputusan & Kesimpulan \\
\hline $\begin{array}{l}\text { Kelompok } \\
\text { Eksperimen I }\end{array}$ & 0,06992 & 0,0909 & $\begin{array}{c}\mathrm{H}_{0} \\
\text { diterima }\end{array}$ & Normal \\
\hline $\begin{array}{l}\text { Kelompok } \\
\text { Eksperimen II }\end{array}$ & 0,0783 & 0,09043 & $\begin{array}{c}\mathrm{H}_{0} \\
\text { diterima }\end{array}$ & Normal \\
\hline $\begin{array}{l}\text { Gaya belajar } \\
\text { Auditorial }\end{array}$ & 0,10728 & 0,136713 & $\begin{array}{c}\mathrm{H}_{0} \\
\text { diterima }\end{array}$ & Normal \\
\hline $\begin{array}{l}\text { Gaya belajar } \\
\text { Kinestetik }\end{array}$ & 0,07371 & 0,1098948 & $\begin{array}{r}\mathrm{H}_{0} \\
\text { diterima }\end{array}$ & Normal \\
\hline $\begin{array}{l}\text { Gaya belajar } \\
\text { Visual }\end{array}$ & 0,08324 & 0,09667 & $\begin{array}{r}\mathrm{H}_{0} \\
\text { diterima }\end{array}$ & Normal \\
\hline
\end{tabular}

Berdasarkan hasil uji normalitas pada tabel di atas tampak bahwa $L_{\text {maks }}$ pada setiap kelompok eksperimen dan gaya belajar kurang dari $\mathrm{L}_{0,05 ; \mathrm{n}}$. Hal ini berarti pada taraf signifikansi 0,05 hipotesis nol untuk setiap kelompok eksperimen dan gaya belajar diterima. Dengan demikian dapat disimpulkan bahwa data pada setiap kelompok berasal dari populasi yang berdistribusi normal.

\section{b. Uji homogenitas}

Uji homogenitas digunakan untuk mengetahui apakah sampel penelitian mempunyai variansi yang sama. Uji homogenitas menggunakan metode Barlett dengan statistik uji Chi Kuadrat. Berdasarkan uji homogenitas antar kelompok eksperimen dan antar gaya belajar yang telah dilakukan diperoleh harga statistik uji untuk 
taraf signifikansi 0,05 pada kelompok eksperimen dan gaya belajar sebagai berikut:

Tabel 6. Hasil Uji Homogenitas

\begin{tabular}{|l|c|c|c|l|l|}
\hline \multicolumn{1}{|c|}{ Sampel } & \multicolumn{1}{c|}{$\mathbf{k}$} & \multicolumn{1}{c|}{$\boldsymbol{\chi}_{\text {obs }}^{\mathbf{2}}$} & $\boldsymbol{\chi}_{\mathbf{0}, \mathbf{0 5} \boldsymbol{n} \mathbf{n}}$ & Keputusan & Kesimpulan \\
\hline $\begin{array}{l}\text { Kelompok } \\
\text { Eksperimen }\end{array}$ & 2 & 1,668 & 3,841 & $\begin{array}{l}\mathrm{H}_{0} \\
\text { diterima }\end{array}$ & Homogen \\
\hline Gaya Belajar & 3 & 0,9224 & 5,991 & $\begin{array}{l}\mathrm{H}_{0} \\
\text { diterima }\end{array}$ & Homogen \\
\hline
\end{tabular}

Dari tabel di atas tampak bahwa $\chi_{o b s}^{2}$ lebih kecil dari $\chi_{0,05 ; n}^{2}$, dengan keputusan uji $\mathrm{H}_{0}$ diterima. Berarti dapat disimpulkan bahwa kedua kelompok eksperimen dan ketiga gaya belajar memiliki variansi sama. Dengan kata lain, kedua kelompok eksperimen adalah homogen.

\section{Uji Hipotesis}

Prosedur uji hipotesis dalam penelitian ini menggunakan Analisis Variansi Dua Jalan (ANAVA) dengan sel tak sama. Hasil dari perhitungan yang telah dilakukan disajikan dalam tabel berikut:

Tabel 7. Rangkuman Analisis Variansi Dua Jalan Dengan Sel Tak Sama

\begin{tabular}{|l|c|c|c|c|c|l|}
\hline \multicolumn{1}{|c|}{ Sumber } & JK & $\mathrm{dK}$ & \multicolumn{1}{c|}{ RK } & $\mathbf{F}_{\text {hitung }}$ & $\mathbf{F}_{\text {tabel }}$ & Keputusan \\
\hline $\begin{array}{l}\text { Strategi } \\
\text { pembelajaran } \\
\text { (A) }\end{array}$ & 8,9591 & 1 & 8,9591 & 4,2773 & 3,84 & $\mathrm{H}_{0}$ ditolak \\
\hline $\begin{array}{l}\text { Gaya belajar } \\
(\mathrm{B})\end{array}$ & 1,4184 & 2 & 0,7092 & 0,3386 & 3,00 & $\begin{array}{l}\mathrm{H}_{0} \\
\text { diterima }\end{array}$ \\
\hline Interaksi (AB) & 3,1475 & 2 & 1,5738 & 0,7514 & 3,00 & $\begin{array}{l}\mathrm{H}_{0} \\
\text { diterima }\end{array}$ \\
\hline Galat & 387,4865 & 185 & 2,0945 & - & - & - \\
\hline Total & 401,0116 & 190 & - & - & - & - \\
\hline
\end{tabular}

Berdasarkan tabel di atas tampak bahwa untuk strategi pembelajaran diperoleh $F_{a}=4,2773>F_{\text {tabel }}=3,84$. Berarti keputusan uji untuk strategi pembelajaran adalah hipotesis nol ditolak. Sedangkan untuk gaya belajar diperoleh nilai $F_{b}=0,3386<F_{\text {tabel }}=3,00$ dan 
Eksperimentasi Strategi Pembelajaran Matematika Berbasis Masalah (Problem Solving) dan Kontekstual (Contextual Teaching and Learning) Ditinjau Dari Gaya Belajar Siswa di SMPN 1 Martapura

untuk interaksi antara pendekatan pembelajaran dan gaya belajar diperoleh nilai $F_{b}=0,7514<F_{\text {tabel }}=3,00$. Berarti keputusan uji untuk gaya belajar dan interaksi adalah hipotesis nol diterima. Dengan demikian dapat disimpulkan sebagai berikut:

a. Pada pendekatan pembelajaran (A) $\mathrm{H}_{0}$ ditolak

Terdapat perbedaan efek strategi pembelajaran pada kelompok siswa dengan strategi pembelajaran problem solving dengan kelompok siswa dengan strategi pembelajaran CTL terhadap prestasi matematika siswa. Dengan kata lain, siswa yang diajarkan dengan strategi pembelajaran problem solving memiliki prestasi belajar matematika yang berbeda dari siswa yang diajarkan dengan strategi pembelajaran CTL.

b. Pada gaya belajar (B) $\mathrm{H}_{0}$ diterima

Tidak terdapat perbedaan efek gaya belajar baik pada siswa dengan gaya belajar auditorial, kinestetik atau visual terhadap prestasi matematika siswa. Dengan kata lain, baik siswa dengan gaya belajar auditorial, kinestetik, maupun visual memiliki prestasi matematika yang tidak berbeda.

c. Pada interaksi $(A B) \mathrm{H}_{0}$ diterima

Tidak terdapat interaksi antara strategi pembelajaran dengan gaya belajar terhadap prestasi matematika siswa. Artinya karakteristik perbedaan gaya belajar siswa pada setiap strategi pembelajaran sama. Dengan kata lain, perbedaan prestasi dari masing-masing strategi pembelajaran konsisten pada masing-masing gaya belajar dan adanya perbedaan prestasi belajar dari masingmasing gaya belajar konsisten pada masing-masing strategi pembelajaran. Kesimpulannya perbandingan rataan antar sel mengacu kepada kesimpulan perbandingan rataan marginalnya. 


\section{Pembahasan}

\section{Hipotesis Pertama}

Terdapat perbedaan efek strategi pembelajaran pada kelompok siswa dengan strategi pembelajaran problem solving dengan kelompok siswa dengan strategi pembelajaran CTL terhadap prestasi matematika siswa, serta melihat rerata skor prestasi matematika siswa dalam strategi pembelajaran dengan problem solving sebesar 7,6354 dan dengan strategi pembelajaran CTL sebesar 7,1433. Ini berarti secara umum prestasi matematika siswa pada strategi pembelajaran dengan problem solving lebih baik dari strategi pembelajaran dengan CTL.

Dari hasil analisis di atas dapat disimpulkan bahwa hipoteisis pertama dalam Bab II yang menyatakan "Penggunaan strategi pembelajaran Problem Solving memberikan prestasi lebih baik dibandingkan dengan strategi pembelajaran CTL pada prestasi matematika siswa kelas VII SMPN 1 Martapura dalam pokok bahasan Aritmetika Sosial" terbukti kebenarannya.

Berdasarkan rataan marginal yang diperoleh, menunjukkan bahwa kelompok siswa dengan strategi pembelajaran problem solving memiliki prestasi yang lebih baik dibandingkan dengan kelompok siswa dengan strategi pembelajaran CTL. Hal ini, membuktikan pernyataan Gagne (1996) dalam Martinis Yamin dan Bansu (2009:81) pada Bab II yang menyatakan bahwa "problem solving atau pemecahan masalah adalah tipe belajar yang tingkatannya paling tinggi dan kompleks dibandingkan dengan tipe belajar lainnya" dalam hal ini, yang dimaksud tipe belajar lain adalah CTL.

Hal ini diperkuat oleh penelitian yang telah dilakukan oleh Suyadi (2009) dan Slamet (2005) yang menyatakan bahwa pembelajaran berdasarkan pemecahan masalah (problem solving) lebih baik dari pembelajaran langsung. Dengan demikian, problem solving dapat dijadikan salah satu referensi strategi pembelajaran matematika yang dapat meningkatkan prestasi belajar matematika siswa. 
Eksperimentasi Strategi Pembelajaran Matematika Berbasis Masalah (Problem Solving) dan Kontekstual (Contextual Teaching and Learning) Ditinjau Dari Gaya Belajar Siswa di SMPN 1 Martapura

\section{Hipotesis Kedua}

Tidak terdapat perbedaan efek gaya belajar baik pada siswa dengan gaya belajar auditorial, kinestetik atau visual terhadap prestasi matematika siswa. Ini berarti secara umum prestasi matematika siswa dengan gaya belajar auditorial sama dengan siswa dengan gaya belajar kinestetik dan juga sama dengan siswa dengan gaya belajar visual.

Dengan demikian hipotesis kedua dalam Bab II yang menyatakan "Prestasi matematika siswa dengan gaya belajar auditorial lebih baik daripada prestasi matematika siswa dengan gaya belajar visual dan kinestetik, prestasi matematik siswa dengan gaya belajar kinestetik lebih baik daripada prestasi matematika siswa dengan gaya belajar visual dalam menyelesaikan soal matematika pada pokok bahasan Aritmetika Sosial" tidak terbukti kebenarannya.

Hal ini diperkuat oleh penelitian yang telah dilakukan oleh Nelly Nelli Ma'rifat Sanusi (2009) yang menyatakan bahwa gaya belajar auditorial, kinestetik dan visual memberikan pengaruh yang sama terhadap prestasi belajar matematika. Akan tetapi, hal ini tidak sesuai dengan kajian teori yang menyatakan bahwa siswa dengan gaya belajar auditorial termasuk siswa yang aktif sehingga siswa dengan gaya belajar auditorial akan lebih mudah memahami materi daripada siswa dengan gaya belajar visual dan kinestetik, yang mengakibatkan teori tersebut tidak terbukti kebenarannya dalam penelitian ini.

Adapun beberapa faktor yang dapat menyebabkan tidak adanya perbedaan prestasi matematika siswa dengan gaya belajar auditorial, kinestetik atau visual, baik pada strategi pembelajaran dengan problem solving maupun dengan CTL adalah:

a. Pada umumnya, seluruh siswa mempunyai kemampuan yang sama dalam menyelesaikan soal aritmetika sosial. Hal ini dikarenakan materi aritmetika sosial sering ditemukan dalam kehidupan sehari-hari oleh setiap siswa. Karena permasalahan aritmetika sosial yang dihadapi siswa dalam kehidupan siswa sehari-hari cenderung sama. Mengakibatkan 
kemampuan siswa dalam menyelesaikan soal-soal dan menelaah soalsoal cerita dalam aritmetika sosial cenderung seragam. Kenyataan bahwa cara mengerjakan soal arimetika sosial adalah sama, menyebabkan adanya keseragaman pemahaman siswa. Artinya meskipun siswa memiliki gaya belajar yang berbeda, namun mereka memiliki kemampuan yang sama dalam meyelesaikan soal aritmetika sosial.

b. Dalam proses menyelesaikan soal-soal aritmetika sosial, para siswa pada umumnya melihat contoh soal yang telah diberikan sebelumnya. Sehingga jika diberikan soal yang tidak sesuai dengan contoh soal siswa merasa kesulitan dalam menyelesaikannya. Baik pada siswa dengan pendekatan pembelajaran dengan problem solving maupun CTL. Kenyataan ini mengakibatkan tidak adanya perbedaan kemampuan menyelesaikan soal aritmatika sosial pada siswa dengan gaya belajar auditorial, kinestetik atau visual, baik pada siswa dengan pendekatan pembelajaran dengan problem solving maupun CTL.

\section{Hipotesis Ketiga}

Tidak terdapat interaksi antara strategi pembelajaran dengan gaya belajar terhadap prestasi matematika siswa. Ini berarti, perbandingan sel antar baris dalam satu kolom maupun perbandingan sel antar kolom dalam satu baris mengikuti perlakuan yang ada pada induknya yaitu pada efek strategi pembelajaran (A) dan pada efek gaya belajar (B).

Dengan memperhatikan hasil hipotesis pertama dan kedua, secara umum siswa dengan strategi pembelajaran problem solving memiliki prestasi yang sama pada masing-masing gaya belajar (auditorial, kinestetik, dan visual). Dengan kata lain, pada kelompok siswa dengan strategi pembelajaran problem solving, siswa dengan gaya belajar auditorial memiliki prestasi matematika yang sama dengan siswa dengan gaya belajar kinestetik, siswa dengan gaya belajar kinestetik juga memiliki prestasi matematika yang sama dengan siswa dengan gaya belajar visual. Dengan demikian hipotesis ketiga dalam Bab II yang menyatakan bahwa "Pada 
Eksperimentasi Strategi Pembelajaran Matematika Berbasis Masalah (Problem Solving) dan Kontekstual (Contextual Teaching and Learning) Ditinjau Dari Gaya Belajar Siswa di SMPN 1 Martapura

kelas dengan metode pembelajaran Problem Solving. Prestasi matematika siswa dengan gaya belajar auditorial lebih baik daripada prestasi matematika siswa dengan gaya belajar visual dan kinestetik, prestasi matematik siswa dengan gaya belajar kinestetik lebih baik daripada prestasi matematika siswa dengan gaya belajar visual dalam menyelesaikan soal matematika pada pokok bahasan Aritmetika Sosial" tidak terbukti kebenarannya. Hasil dari uji hipotesis ketiga ini tidak sesuai dengan kajian teori yang menyatakan bahwa siswa dengan gaya belajar auditorial termasuk siswa yang aktif sehingga siswa dengan gaya belajar auditorial akan lebih mudah memahami materi daripada siswa dengan gaya belajar visual dan kinestetik. Hal ini juga tidak sesuai dengan hasil penelitian yang dilakukan oleh Aning Wulandari (2010) yang menyatakan bahwa "pada kemampuan menyelesaikan soal cerita dengan pembelajaran langsung, hasil belajar siswa dengan gaya belajar visual lebih baik daripada dengan siswa dengan gaya belajar kinestetik”.

Adapun faktor secara umum yang dapat menyebabkan tidak adanya perbedaan prestasi matematika siswa dengan gaya belajar auditorial, kinestetik atau visual pada pendekatan pembelajaran telah dipaparkan pada penjelasan hipotesis kedua.

\section{Hipotesis Keempat}

Tidak terdapat interaksi antara strategi pembelajaran dengan gaya belajar terhadap prestasi matematika siswa. Ini berarti, perbandingan sel antar baris dalam satu kolom maupun perbandingan sel antar kolom dalam satu baris mengikuti perlakuan yang ada pada induknya yaitu pada efek strategi pembelajaran (A) dan pada efek gaya belajar (B).

Dengan memperhatikan hasil hipotesis pertama dan kedua, secara umum siswa dengan strategi pembelajaran CTL memiliki prestasi yang sama pada masing-masing gaya belajar (auditorial, kinestetik, dan visual). Dengan kata lain, pada kelompok siswa dengan pendekatan pembelajran CTL, siswa dengan gaya belajar auditorial memiliki prestasi matematika yang sama dengan siswa dengan gaya belajar kinestetik, siswa dengan gaya 
belajar kinestetik juga memiliki prestasi matematika yang sama dengan siswa dengan gaya belajar visual. Dengan demikian hipotesis keempat dalam Bab II yang menyatakan bahwa "Pada kelas dengan strategi pembelajaran CTL, Prestasi matematika siswa dengan gaya belajar auditorial lebih baik daripada prestasi matematika siswa dengan gaya belajar visual dan kinestetik, prestasi matematik siswa dengan gaya belajar kinestetik lebih baik daripada prestasi matematika siswa dengan gaya belajar visual dalam menyelesaikan soal matematika pada pokok bahasan Aritmetika Sosial" tidak terbukti kebenarannya.

Hasil dari hipotesis ke empat ini menegaskan bahwa penelitian yang telah dilakukan Aning Wulandari (2010) yang menyatakan bahwa "pada kemampuan menyelesaikan soal cerita dengan pendekatan kontekstual, hasil belajar siswa dengan gaya belajar visual lebih baik daripada siswa dengan gaya belajar kinestetik" tidak berlaku untuk pembelajaran kotekstual pada materi aritmetika sosial.

Adapun faktor secara umum yang dapat menyebabkan tidak adanya perbedaan prestasi matematika siswa dengan gaya belajar auditorial, kinestetik atau visual pada pendekatan pembelajaran dengan problem solving telah dipaparkan pada penjelasan hipotesis kedua.

\section{Kesimpulan}

Berdasarkan hasil penelitian dan pembahasan penelitian dapat disimpulkan bahwa pada siswa kelas VII SMPN 1 Martapura Kabupaten Banjar tahun pelajaran 2014-2015, khususnya pada materi Aritmetika Sosial

1. Prestasi belajar matematika siswa dengan strategi pembelajaran problem solving lebih baik dibandingkan dengan prestasi belajar matematika siswa dengan strategi pembelajaran CTL.

2. Prestasi belajar matematika siswa dengan gaya belajar auditorial sama dengan prestasi belajar matematika siswa dengan gaya belajar kinestetik, prestasi belajar matematika siswa dengan gaya belajar kinestetik sama dengan prestasi belajar matematika siswa dengan gaya belajar visual, 
Eksperimentasi Strategi Pembelajaran Matematika Berbasis Masalah (Problem Solving) dan Kontekstual (Contextual Teaching and Learning) Ditinjau Dari Gaya Belajar Siswa di SMPN 1 Martapura

prestasi belajar matematika siswa dengan gaya belajar auditorial sama dengan prestasi belajar matematika siswa dengan gaya belajar visual.

3. Pada kelompok siswa dengan strategi pembelajaran problem solving, prestasi belajar matematika siswa dengan gaya belajar auditorial sama dengan prestasi belajar matematika siswa dengan gaya belajar kinestetik, prestasi belajar matematika siswa dengan gaya belajar kinestetik sama dengan prestasi belajar matematika siswa dengan gaya belajar visual, prestasi belajar matematika siswa dengan gaya belajar auditorial sama dengan prestasi belajar matematika siswa dengan gaya belajar visual.

4. Pada kelompok siswa dengan strategi pembelajaran CTL, prestasi belajar matematika siswa dengan gaya belajar auditorial sama dengan prestasi belajar matematika siswa dengan gaya belajar kinestetik, prestasi belajar matematika siswa dengan gaya belajar kinestetik sama dengan prestasi belajar matematika siswa dengan gaya belajar visual, siswa dengan gaya belajar auditorial sama dengan prestasi belajar matematika siswa dengan gaya belajar visual.

\section{Daftar Pustaka}

Aning Wulandari. 2010. Efektivitas Pembelajaran Kontekstual Pada Kemampuan Menyelesaikan Masalah Soal Aljabar Dan Soal Cerita Ditinjau Dari Gaya Belajar Pada Siswa Kelas X (Sepuluh) Madrasah Aliyah Di Kabupaten Bojonegoro. Laporan Penelitian Thesis UNS. Program Pendidikan Matematika Program Pascasarjana Universitas Sebelas Maret.

Budiyono. 2003. Metodologi Penelitian Pendidikan. Surakarta: UNS Press. 2009. Statistika untuk Penelitian, Ed. ke-2. Surakarta: UNS Press.

Chapman, O. 1999. Inservice Teacher Development In Mathematical Problem Solving. Journal of Mathematics Theacher Education, Vol 2, pp 121-142.

Departemen pendidikan nasional. 2006. Standar Isi Mata Pelajaran Matematika SMA/MA Kurikulum 2006. Jakarta: BSNP. 

Ujian Nasional (UN) Tahun Pelajaran 2008/2009. Jakarta: BSNP.

Deporter, B., dan Hernacki, M. 2000. Quantum Learnig: Membiasakan Belajar Nyaman dan Menyenangkan. Terjemahan Alwiyah Abdurrahman. Bandung: Kaifa.

Dian Indriastuti Kusuma Wijaya. 2009. Efektivitas Pembelajaran Matematika Dengan Kontekstual Ditinjau Dari Lingkungan Belajar Pokok Bahasan Aritmetika Social Siswa Kelas Vii Smp Kota Surakarta. Laporan Penelitian Thesis UNS. Program Pendidikan Matematika Program Pascasarjana Universitas Sebelas Maret.

Kelly, C. A. 2006. Using Manipulatives in Mathematical Problem Solving: A Performance Based Analysis. The Montana Mathematics Enthusiast, Vol 3, No 2, pp 184-193.

Kolb, A.Y and Kolb, D. A. 2005 Learning Styles and Learning Spaces: Enhancing Experiential Learning in Higher Education. Academy of Management Learning \& Education, Vol. 4, No. 2, 193-212.

Maasz, J. 2005. A New View Of Mathematics Will Help Mathematics Teachers. Adults Learning Mathematics, Vol 6, No 1, pp 6-18

Mar'atus Sholihah. 2009. Pendekatan CTL (Contextual Teaching And Learning) Pada Materi Aljabar Dan Aritmetika Social Terhadap Prestasi Belajar Matematika Ditinjau Dari Motivasi Siswa Terhadap Matematika. Laporan Penelitian Thesis UNS. Program Pendidikan Matematika Program Pascasarjana Universitas Sebelas Maret.

Nana Sudjana. 2009. Dasar-dasar Proses Belajar dan Mengajar. Bandung: Sinar Baru Algensindo.

Nelli Ma'rifat Sanusi. 2009. Eksperimentasi Pembelajaran Matematika Melalui Pendekatan Realistik Ditinjau dari Gaya Belajar Siswa Kelas $\checkmark$ SD di Kecamatan Leuswisari Tasikmalaya. Laporan Penelitian Thesis UNS. Program Pendidikan Matematika Program Pascasarjana Universitas Sebelas Maret.

Pallapu, P. 2007. Effects of Visual and Verbal Learning Style on Learning. Institute for Learning Styles Journal, Vol 1, page 34-39.

Slamet. 2005. Keefektifan Pembelajaran Pemecahan Masalah Terhadap Kemampuan Penyelesaian Soal Ditinjau Dari Kemandirian Siswa. Laporan Penelitian Thesis UNS. Program Pendidikan Matematika Program Pascasarjana Universitas Sebelas Maret. 
Eksperimentasi Strategi Pembelajaran Matematika Berbasis Masalah (Problem Solving) dan Kontekstual (Contextual Teaching and Learning) Ditinjau Dari Gaya Belajar Siswa di SMPN 1 Martapura

Suharsimi Arikunto. 2006. Prosedur Penelitian Suatu Pendekatan Praktek. Edisi revisi VI. Jakarta: Rineka Cipta.

Suyadi. 2009. Eksperimentasi Model Pembelajaran Pemecahan Masalah (PROBLEM SOLVING) Pada Materi Pokok Lingkaran Terhadap Prestasi Belajar Matematika Ditinjau Dari Motivasi Belajar Pada Siswa Kelas 8 SMP Di Kabupaten Sragen. Laporan Penelitian Thesis UNS. Program Pendidikan Matematika Program Pascasarjana Universitas Sebelas Maret.

Wina Sanjaya. 2010. Strategi Pembelajaran Beroerientasi Standar Proses Pendidikan. Jakarta: Kencana.

WWW.Zainurie.wordpress.com. 2009. "Pakar Matematika" Bicara Tentang, Prestasi Pendidikan Matematika Indonesia. Diakses pada tanggal 5-11-2014.

\section{Arif Ganda Nugroho}

Dosen Prodi PMTK, IAIN Antasari Banjarmasin

E-mail: arif.gnugroho@gmail.com 
Arif Ganda Nugroho 